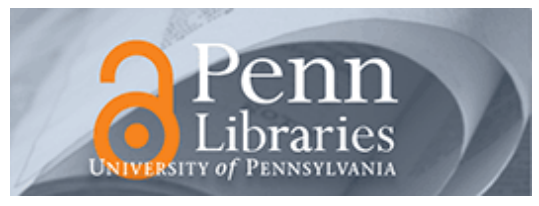

Studies in Visual Communication

Volume 8

Issue 3 Summer 1982

Article 6

1982

\title{
From the Hopi Snake Dance to "The Ten Commandments": Edward S. Curtis as Filmmaker
}

Mick Gidley

Recommended Citation

Gidley, M. (1982). From the Hopi Snake Dance to "The Ten Commandments": Edward S. Curtis as Filmmaker. 8 (3), 70-79. Retrieved from https://repository.upenn.edu/svc/vol8/iss3/6

This paper is posted at ScholarlyCommons. https://repository.upenn.edu/svc/vol8/iss3/6

For more information, please contact repository@pobox.upenn.edu. 
From the Hopi Snake Dance to "The Ten Commandments": Edward S. Curtis as Filmmaker 


\title{
From the Hopi Snake Dance to "The Ten Commandments": Edward S. Curtis as Filmmaker
}

\author{
Mick Gidley
}

In the Land of the Head-Hunters, Edward S. Curtis's documentary feature film on the Kwakiutl of British Columbia, and the earliest movie of its kind, was released in 1914 (see Figure 1). The following year the poet Vachel Lindsay wrote of it in markedly laudatory terms in what probably constitutes the very first formulation of an aesthetic of the cinema, his book The Art of the Moving Picture:

\begin{abstract}
The photoplay of the American Indian should in most instances be planned as a bronze in action. The tribes should not move so rapidly that the panther-like elasticity is lost in the riding, running, and scalping. On the other hand, the aborigines should be far from the temperateness of marble.

Mr. Edward S. Curtis, the super-photographer, has made an Ethnological collection of photographs of American Indians. This work of a lifetime, a supreme art achievement, shows the native as a figure in bronze. Mr. Curtis's photoplay, The Land of the Head Hunters [sic] (World Film Corporation), a romance of the Indians of the North-West, abounds in noble bronzes. [Lindsay 1922:114] ${ }^{1}$
\end{abstract}

It may be that Lindsay's attention to the film was partly a result of his own residence in Spokane for a time, and his consequent extra knowledge of artistic activities in the Pacific Northwest. In any event, after this initial praise of Curtis's film as a sculpture-in-motion, it occasioned nothing more than a strange 50 year silence.

Mick Gidley is Chairman of American and Commonwealth Arts at the University of Exeter, England. He edits the American Arts Pamphlet Series and has published a number of works on American literary and cultural topics, including Kopet: A Documentary Narrative of Chief Joseph's Last Years (University of Washington Press, 1981).

\section{The Work of Holm and Quimby}

The exciting work of Bill Holm and George Quimbyfirst in reissuing the film in edited form as In the Land of the War Canoes (1973), ${ }^{2}$ then in writing Edward S. Curtis in the Land of the War Canoes: A Pioneer Cinematographer in the Pacific Northwest (1980) - has done much to make amends for earlier neglect. Their book makes an extremely valuable contribution in at least five respects.

First, it gives a thorough account of how they discovered the film, came to edit it, and added a soundtrack, including details of the changes made.

Second, by using and reproducing a marvelous series of photographs which I traced for them, Holm and Quimby are able to offer a detailed reconstruction of the process by which the film was made; these photographs, by Curtis's cameraman and general business assistant, Edmund A. Schwinke, actually show such things as Curtis relaxing with his crew of actors, and George Hunt, the principal Kwakiutl informant, giving orders through a megaphone (see Figures 2 and 3 ).

Third, Holm's deep knowledge of the Kwakiutl and his collection of individual memories from among them enable Holm and Quimby to provide an assessment of the relationship between a people and their ethnological filmmakers which it would be impossible, I think, to supersede.

Fourth, the biographical accounts of Curtis and of various of his assistants-his brother Asahel Curtis, his nephew-in-law William W. Phillips, and William E. Myers, his chief ethnologist-are probably as accurate and as complete as reliance on the published record alone will allow. Notably effective use is made of city directories, Who's Who in America, and newspaper reports; moreover, through work on legal records, new information is provided on the Curtis family's early years in the Puget Sound region. The book provides a reliable outline both of Curtis and of the creation of his major work. The North American Indian (Cambridge, Massachusetts and Norwood, Connecticut, 1907-1930), which consisted of 20 volumes of illustrated text and 20 portfolios of photogravures.

Finally, a firm connection is established between Curtis and the much-better-known endeavors of Robert Flaherty, creator of what has hitherto been considered the first full-length narrative documentary, Nanook of the North (1922). Here Holm and Quimby rely on the evidence of Frances Flaherty's diary, as transcribed by Jay Ruby of Temple University.

My purposes here are to outline some of Edward S. Curtis's film activities prior to his British Columbia film; to fill out the story of that movie somewhat by reference to previously unpublished materials; and to offer some preliminary findings - clues, really, as to possible avenues of future research-on Curtis's later activities in the film world. 


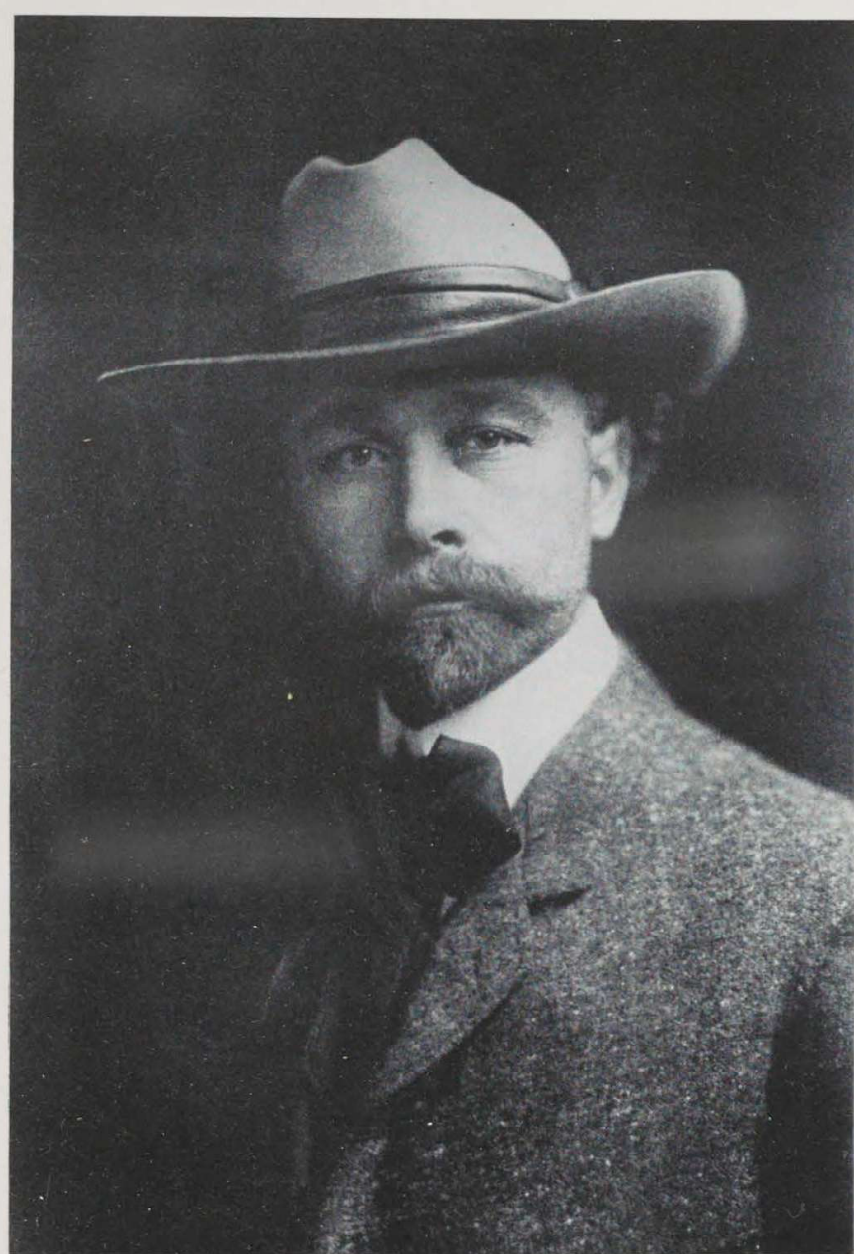

Flgure 1 Edward S. Curtis, ca. 1905. Photograph by Curtis's studio manager, Adolph F. Muhr.

\section{Curtis's Early Film Activity}

Earle R. Forrest, the writer and photographer, recorded in his book The Snake Dance of the Hopi Indians (1961) that Curtis had made movie footage of the Oraibi snake dance as early as 1906:

I heard at the time that he had paid the Snake Society two hundred dollars for the privilege of filming motion pictures in the Snake Kiva, but I cannot vouch for this statement. In a recent letter, Robert $E$. Callahan, of Los Angeles, declared that making pictures in the Indian country in 1906 could hardly have been possible; that the process had not been adequately developed at that time. He should have told that to Mr. Curtis, who took those movies and the next winter toured eastern states showing them in theatres, once in Pittsburgh, Pennsylvania.

[Forrest 1961:54-55]

Forrest is, in the main, a very reliable source on photographic matters; for example, long before I got corroboration of the fact for myself, he wrote to Ralph

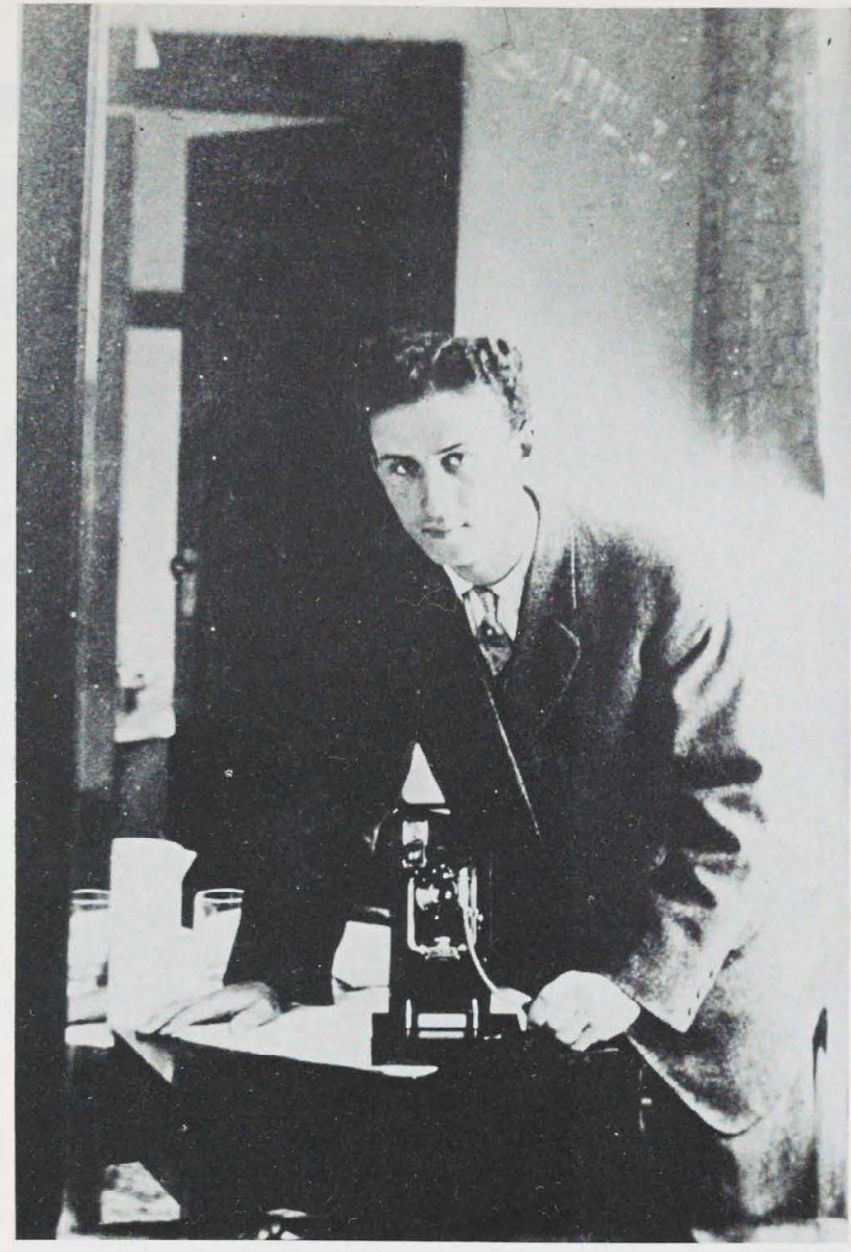

Flgure 2 Edmund August Schwinke: a previously unpublished self-portrait taken through a mirror in September 1912.

Andrews, the photo-historian, to tell him that A. F. Muhr (later to be Curtis's Seattle studio manager) was the actual photographer of the 1898 Trans-Mississippi Omaha Exposition Indian pictures copyrighted by F. A. Rinehart (see Figure 2). ${ }^{3}$ Curtis himself, in the course of a speech delivered during the winter of 1906-1907, referred to his "photographic and other equipment" as if it normally included the following items: "several $61 / 2 \times 81 / 2$ cameras, a motion picture machine, phonograph for recording songs

(Gidley 1978, emphasis added). Moreover, the 1906 summer fieldwork was largely devoted to various tribes of the Southwest. ${ }^{4}$

However, other evidence suggests that the motion picture work began even earlier. The Portland Oregonian of January 15, 1905, carried an item devoted to Curtis and one of his illustrated talks which had the following subheading: "New and Remarkable 'Motion Pictures' of Snake Dance and Other Mystic Ceremonies." 5 This implies that the films were made during the summer of 1904. The Seattle Times for May 22, 1904, told the story of the first such motion picture: 


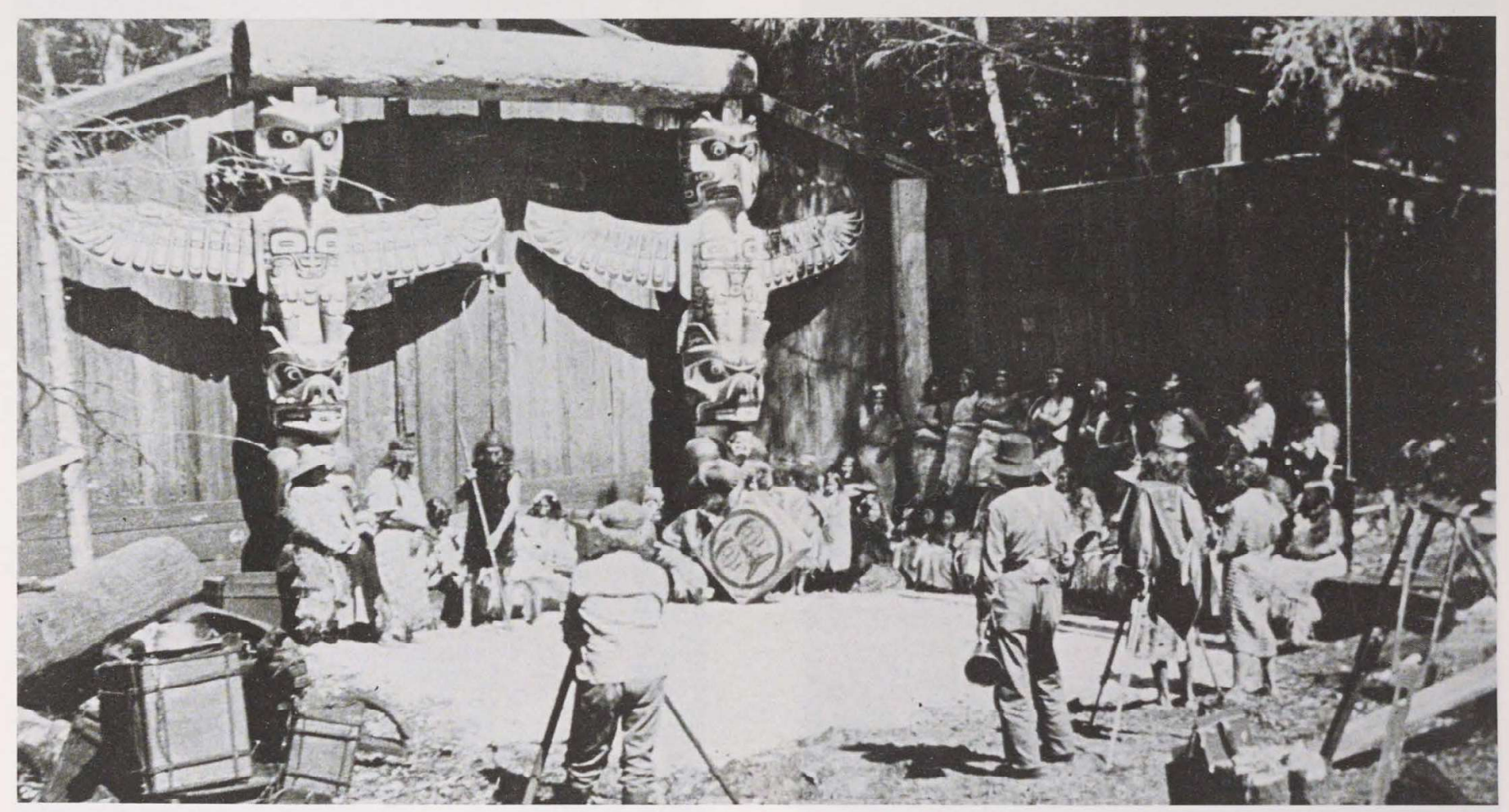

Figure 3 One of Schwinke's views of the filming process, showing Boas's and Curtis's Kwakiutl informant, George Hunt, megaphone in hand, in May 1914.

When Mr. Curtis was in Washington, D.C., recently, government scientists who have devoted a lifetime to the study of Indians, chanced to mention the great Yabachi dance. It seems this dance is hidden among the most sacred rites of the Navajos. It is a ceremony that lasts nine days, all told. ... Smithsonian Institution men told Mr. Curtis that pictures of the dance... would be priceless from the standpoint of the Indian historian. But they also told him that the government had been working to get the views for twenty years without result, and ... had reached the conclusion that it was beyond the pale of the possible. ... Curtis started for the land of the Navajo. This trip he took with him a moving picture machine, something he had never carried before. To all questions he answered: "I am going to Arizona. I don't know how long I will be gone." And he went to Arizona, and he stayed just long enough to accomplish that which Uncle Sam, with all his power and authority, had tried for two decades to do and failed. ... In addition to individual pictures of the masked dancers and the "fool," Curtis brought back a "moving picture" of the dance itself something that thrown upon the screen will convey to the onlooker the exact and lifelike picture of a dance that, in its reality, had never been seen by light of day, or had been looked upon by the eyes of a white man.
In November 1904 the same newspaper recorded a similar Curtis coup in the case of the Hopi snake dance (see Figure 4). He had rented an Oraibi roof top; "it was from this roof," he said, "[that] I proposed to work the motion picture machine or kinetoscope. My other work I planned to do from the ground and get in as close and often as I could."7 Teri C. McLuhan's film, The Shadow Catcher: Edward S. Curtis and the North American Indian (1975), excerpts some of this early footage, including parts of the Yebichai and snake dance ceremonies. ${ }^{8}$

The other reason for favoring 1904 over 1906 as the motion picture year is that in 1906 Curtis himself actually danced in the snake ceremony. On September 26, 1906, he wrote from Seattle to report the season's activities to Frederick Webb Hodge, the editor of The North American Indian; "I was fortunate enough," his final paragraph reads, "to be able to go through the whole Snake ceremony participating and in fact doing everything that a Snake man would do except the part in the public part of the Snake dance. The only reason I did not do that was that I feared newspaper publicity and missionary criticism." Unfortunately, over the years Curtis came to emphasize his participation in such events precisely to achieve publicity. The most extreme such instance, in that the story was obviously put together by a notably sensationalist reporter, appeared in the Seattle Post-Intelligencer for November 8, 1908: 
"In the Hopi snake ceremony, which is intensely dramatic, I acted as a priest."

"Do you mean that you are a Pueblo priest in good standing?" asked the reporter.

"Yes," said Mr. Curtis, "and I am a priest in other nations. ... The thing is to become a member of a secret order. That is the only way to learn their secrets.

Every ceremonial group you get into makes it easier to get into others. ... My belonging to the Snake Order in Arizona helped me greatly when I tried to get into a ceremonial order in Alaska."

"You were a priest in Alaska, too?"

"Oh, yes." .

"But what would the Alaska Indians know about what was done so far off as Arizona?"

"Oh, when they saw my photographs of the snake dance and heard the phonograph records-"

"Do you mean to say that you photographed and phonographed these ceremonies while you were officiating as priest?"

"Yes. ..." "Being a priest ... . " resumed Mr. Curtis, "is not an unmixed blessing. I remember once in the Navajo desert ... when I had participated in [the Yebichai] ceremony - day and night, you understand, for nine daysand when I left them at dawn on the last day if any one had tried to pick up my trail he would have found it forty feet wide, though I was trying to walk a straight line."

The likely basis for yarns like this is that in lectures Curtis would show his photographs and movies while very vividly describing his personal involvement with the people concerned. Indeed, it is possible that such a conflation of years occurred in Forrest's mind: he saw Curtis in the summer of 1906 and later assumed that the movies he saw in the winter of 1906-1907 were made then (see Figure 5). ${ }^{11}$

The most elaborate lecture-performance of Curtis's career was the "musicale" or "picture-opera" delivered in 1911 and 1912 in such places as Carnegie Hall in New York, the Belasco Theatre in Washington, D.C., the Metropolitan Theatre in Seattle, and numerous other venues around the nation. It included speech, lantern slides, music set by Henry F. Gilbert and performed by a small orchestra, and-most important for our present purposes-motion pictures. ${ }^{12}$ Part of an unpublished typed script for one of these performances reads as follows:

At the close of the public ceremony ... the priests race for the desert ... the theory being that the snakes have been taken from the world's quarters, and must be returned there.

PICTURES

BLANK

MOTION PICTURE SNAKE DANCE

No 7 BLANK

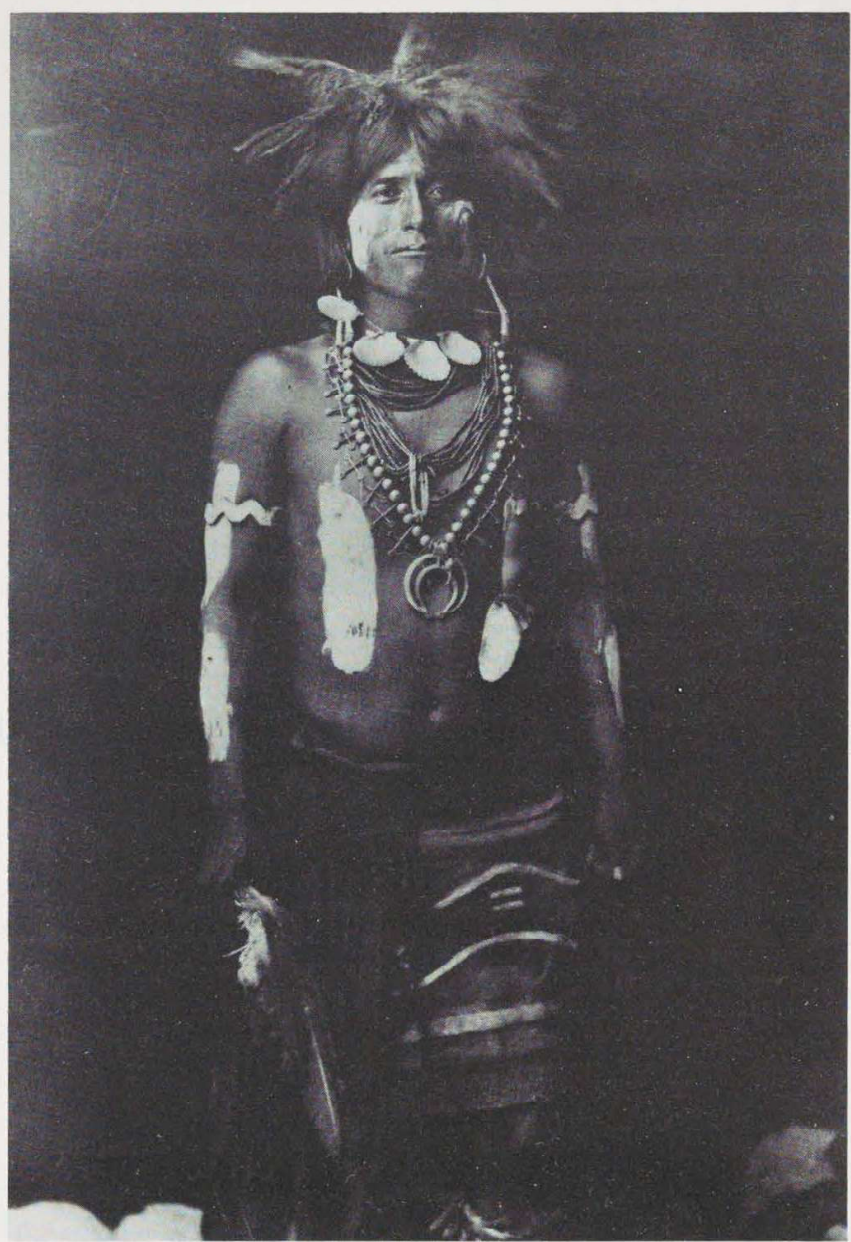

Figure 4 Hopi snake priest, 1904. Photographed by Curtis.

The popular-if not commercial-success of these performances probably prompted Curtis to think in terms of the increasingly popular form, the motion picture itself. Another unpublished typed script has an interesting third section:

III. The Tribes of British Columbia, and their remarkable ceremonial life. Pictures show the general life and manners. "The Kominaka Dance," or dance of the skulls. The Whaler. The Whale Ceremony. Motion Picture, "Dance of the Mummy." "On the Shores of the North Pacific," a dissolving composition depicting life by the moonlit ocean. This series of pictures ... contains some of the most remarkable ever taken of the secret rites of Indians. ${ }^{13}$

Since this same script contains references to the music composed especially for the 1911 tour, it is reasonable to suppose that Curtis had at that time already conceived part of what was to become In the Land of the Head-Hunters (see Figure 6); he had certainly made still photographs of Hamatsa ceremonies, the "Dance of the Mummy," and his narrative documentary was to include a motion picture version of what is called here "the dance of the skulls" (Rice 1976; cf. Holm and Quimby 1980:33). 


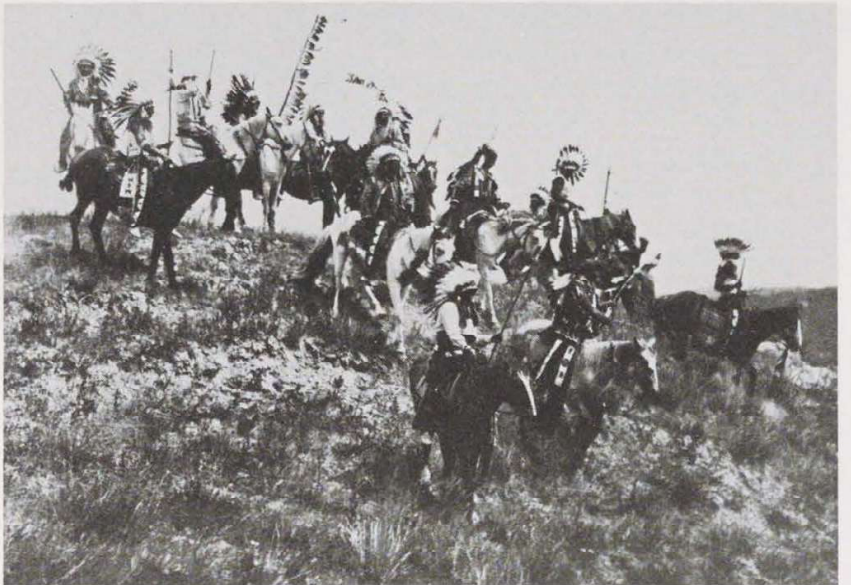

Figure 5 A group of Sioux reenact, for Curtis's camera, in 1907 , a war party of days gone by.

Figure 6 Goat, one of the Kwakiutl ceremonial figures filmed by Curtis for In the Land of the Head-Hunters in 1914. This is a previously unpublished photograph by Schwinke.

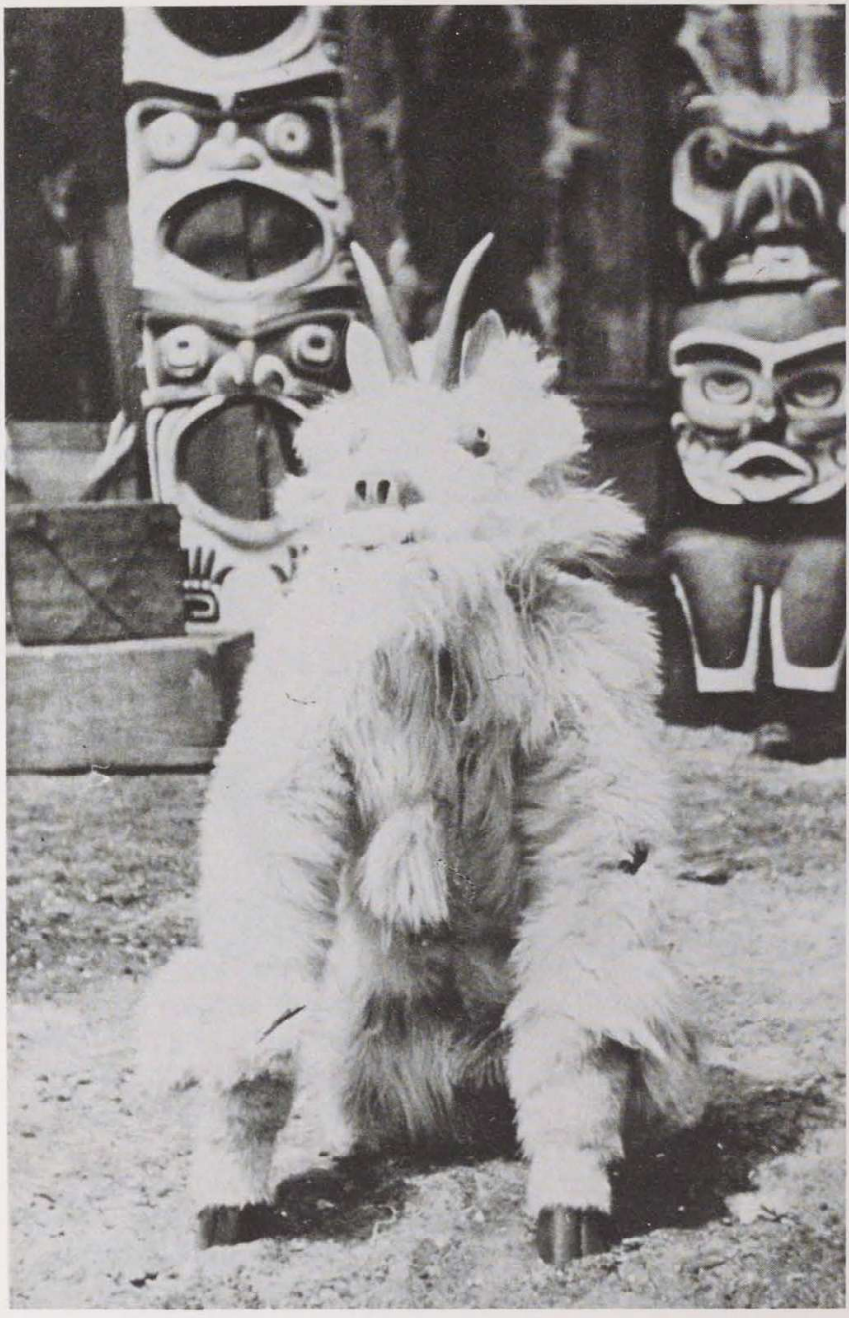

The positive print was finally made from the negative in the middle of October, 1914, ${ }^{17}$ and Curtis sent complimentary tickets, on December 1, to the curator of ethnology at the American Museum of Natural History, Clark Wissler, and also included some for Herbert J. Spinden, another leading ethnologist of the time:

You will no doubt recall our discussion on Indian motion pictures. Following the plan I had in mind at that time, I have produced one dealing with the tribes of the British Columbia coast and it is to have its initial showing on December 7th. I am enclosing seats and hope you can join us.

I think you will find much in it of interest. The picture is a compromise between what I would like to make, if I was in a position to say - "the public be damned" - and what I think the public will support.

I am enclosing a couple of additional tickets which I would like to have you pass on to Mr. Spindon [sic] if he is in town. ${ }^{18}$ 
The only two contemporary reviews of the film I have been able to trace were both highly complimentary. The one by W. Stephen Bush in The Moving Picture World (reproduced very fully in Holm and Quimby) went so far as to call it "a gem of the motion picture art" which has "never been surpassed" (Holm and Quimby 1980:13-14). The other, an anonymous paean of praise which has not been quoted since its original appearance in the Independent, invokes ideas similar to the sculpture-in-motion view expressed by Vachel Lindsay:

It was thought to be a great educational advance when the American Museum of Natural History and the Smithsonian set up groups of Indians modeled in wax and clothed in their everyday or gala costumes. But now a further step of equal importance has been taken by Edward S. Curtis. ... The masks and costumes of the eagle and the bear which seemed merely grotesque when we saw them hung up in rows in the showcase at the museum become effective, even awe-inspiring, when seen on giant forms on the prow of a canoe filled with victorious warriors. ....Mr. Curtis appreciates the effectiveness of the silhouette and the shadow and he is not afraid to point his camera in the face of the sun, contrary to the instructions of the Kodak primer. The scenes that elicited most applause from the audience were after all not those of Indian combats, but those of waves and clouds at sunset, the herd of sea lions leaping from the rocks and the fleet of canoes being driven swiftly forward.

The stirring quality of the film's photography and the educational impact of what Lindsay called its "noble bronzes" must have stayed in the minds of staff members at the American Museum of Natural History. In the early twenties - when, as we shall see, Curtis was engaged in another part of the film world-Pliny Earl Goddard, then curator of ethnology, approached Curtis in the hope of buying a print of In the Land of the Head-Hunters. Goddard wrote on January 25, 1923, and then again on March 9:

I have a strong feeling that your film ought to be preserved in some institution like our museum and besides we can make excellent use of it for our lecture work. You know how public institutions are. They are often out of money. This is the beginning of a year, however, and I am hopeful that some money might be found for such a purchase. If you will give your price I will do what I can toward securing it.

Curtis replied affirmatively from his Los Angeles studio at 668 South Rampart on March 1, 1923, adding, "The picture as now arranged is approximately 6,000 feet in length. As originally put out, while I had it on in New York, it was 10,000 feet. I question however the loss of much that was really vital in its trimming down. Few important incidents were left out; the trimming was largely in the form of shortening scenes."
This exchange marked the opening of protracted negotiation by correspondence between the two parties, and its elements are implicit here. The museum procrastinated, primarily because of lack of funds, and because Curtis's print of the film was physically in less than a fully satisfactory state. In a letter of January 17, 1924, a year after his initial inquiry, Goddard summarized the museum view:

\begin{abstract}
You will think I have been very slow in regard to the Head-Hunter films. The Curator of the Department of Education last fall informed me that he could not purchase the film for his department. I decided, however, to keep it with the hope that some other arrangements could be made. Recently I ran it for Professor Franz Boas to see. He thought several sections of it should most certainly be preserved as a record. This had been my opinion, but since I had seen very little of Northwest Coast life I could not speak with authority. Our budget for 1924 is not complete but I am informed that it is not likely that there will be funds for the purchase of the film. When I consider a thing so essential as this, I never give it up for the lack of money.

What I really want is a negative of about 1,000 or 1,500 feet of the film covering in particular the dances and boat scenes. This negative, of course, could be made from a fresh positive, hardly from the positive that I have here.
\end{abstract}

Goddard went on to suggest a joint purchase with the collector George G. Heye, originator of the Museum of the American Indian (of which, interestingly enough, Frederick Webb Hodge had become director). Clearly, what Boas and Goddard wanted was the film's set pieces; they were not interested in that as pect of it which, from the viewpoint of film history, makes it unique in its own time, however absurd the story is in some respects. Moreover, it was precisely "dances," "boat scenes," games, and the like that Boas himself had the Kwakiutl perform "as a record" for his movie camera a few years later. ${ }^{20}$ This indicates that Boas and Goddard, unlike Flaherty, did not understand the credibility that, paradoxically, fictional narrative - even "romance," if we agree with Vachel Lindsay-achieves. As Jay Ruby has said elsewhere, Curtis and Boas represent completely different approaches to anthropology. ${ }^{21}$

In 1924 the American Museum of Natural History was not the only party running out of money. On October 8, Curtis wired that because he was short of funds he would sell the "master print and negative" for $\$ 1,500$. A week later, on October 16 , he sent the following letter: 


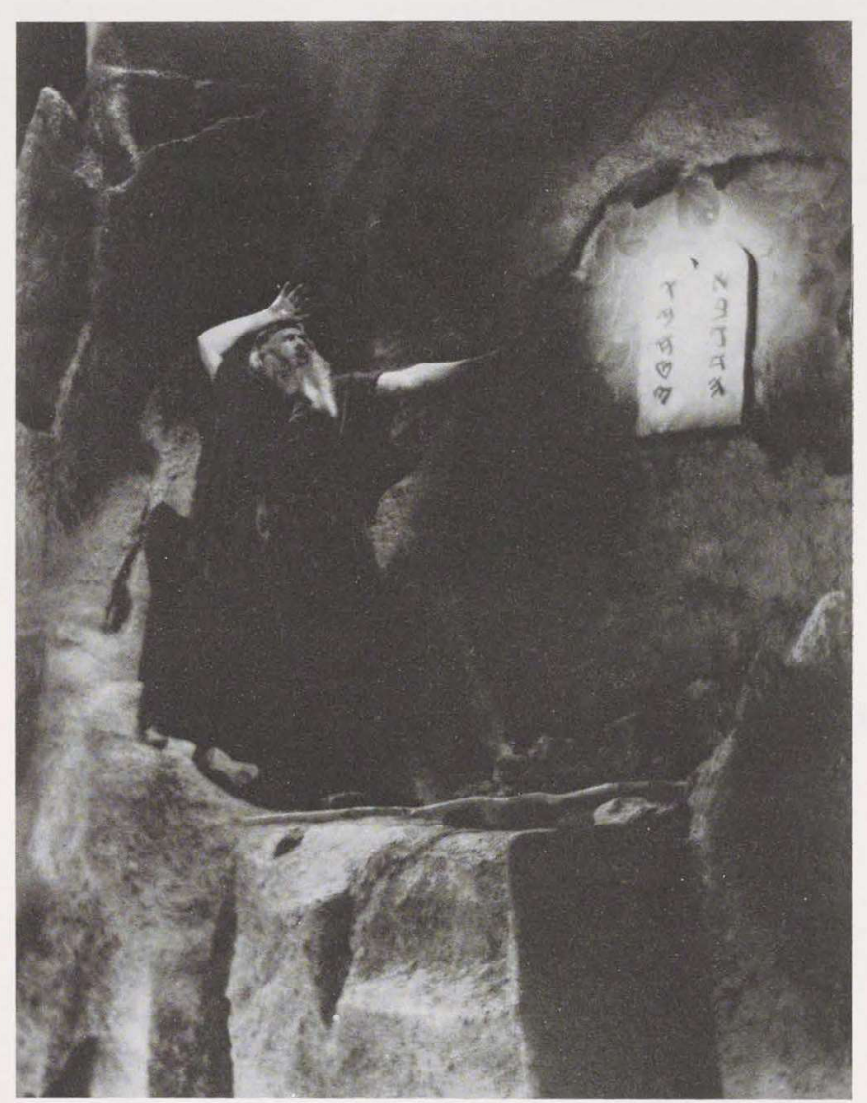

Figure 7 A scene from Cecil B. De Mille's The Ten Commandments, 1923, as photographed by Curtis. (Courtesy California Historical Society.)

I shipped the film yesterday and included in the case first the negative which I think is complete. However, fearing that it might not be, I have sent the positive to you; also, I have included about a thousand feet of extra negative as it may contain some bits which may be of value to you, and I also included a few pieces of positive print which may not be included in the assembled print. I am enclosing a bill covering the matter; also, it is understood by this letter that I relinquish any claim to the copyright upon the film.

Unfortunately, I was unable to trace what happened to all this footage thereafter. ${ }^{22}$ In a postscript to his letter, Curtis asked for the return of any unwanted positive film, but there is no record of any such transaction. Thus, it may or may not be the case that the film George Quimby received at the Field Museum in 1947 was a part (or the whole) of the footage that Curtis sold in 1924.

\section{Curtis's Later Filmmaking}

Gifford Pinchot, a close associate of Theodore Roosevelt for many years, a keen outdoorsman, head of the U.S. Forest Service, and later governor of Pennsylvania, was acquainted with Curtis from at least the time of their participation in the Harriman Alaska Expedition of 1899. He encouraged Curtis, subscribed to The North American Indian, and even lent him money. Curtis would often write to subscribers on the progress of the project and associated activities. In this way he came to tell Pinchot of his movie activities, including the filming of seal and whale hunting for In the Land of the Head-Hunters. ${ }^{23}$

One letter, of June 27,1915 , written mainly to thank Pinchot for a hefty loan, ends with these words: "I have just completed my motion picture of the Yosemite, and feel delighted with it. It is a wonderful region, and I was there at the season of the year when the waterfalls were at their best." This motion picture must be the same one to which Curtis referred in a couple of letters to Edmund Schwinke that are reprinted in Holm and Quimby. He mentioned the possibility of "a month's motion picture work and scenic stuff" in February which, by May, had become a "picture tour of the beauty spots of America" with plans for "fifty-two weeks of a scenic picture a week. The stills are going to Leslie's, and the motion pictures going through motion picture channels"; they were to start at the Grand Canyon, then proceed to Yosemite and Yellowstone. ${ }^{24}$ As we know from the account by Holm and Quimby, Schwinke chose not to participate in this venture, but according to the files of Pinchot's correspondence and certain other letters, at least some such films were made.

On April 22, Curtis asked his old friend Professor Edmond S. Meany of the History Department, University of Washington, for permission to join the Mountaineers, a Northwest climbing club, on its ascent of Mount Rainier that summer, saying that he would be on an "active tour of the United States," working both in "regular photographs and motion photography." From other correspondence in the Meany files, notably a copy of a letter to Curtis from J. H. Weer, chairman of the Mountaineers' Outings Committee, it is clear that Curtis was expected to visit the Mount Rainier National Park during August in the company of the Assistant Secretary of the Interior, Stephen T. Mather. ${ }^{25}$

The following February, on the $22 d$, Curtis wrote to Pinchot, partly to explain a delay in his loan repayment and partly to boast that the Secretary of the In terior had asked him "to go out to the Yellowstone and make a series of motion pictures of the animals." "They tell me," he added, "that there is an unusually large number down in the valley where they are being fed to some extent, and I should be able to get some 
splendid things." By the spring of 1916 the work was probably complete, for Curtis invited Pinchot to a private view of what he termed, in his letter of April 12 , "my park and Indian motion pictures."

Many years later Curtis provided the University of Washington Library with a copy of a letter from Herbert A. Smith (a former editor of The Forester, the journal of the U.S. Forest Service) in which he had asked Curtis to combine his work for Leslie's with securing pictures suitable for Forest Service use as "lantern slide illustrations, and for transparencies, bromides, etc." In an accompanying note, Curtis added a gloss to the effect that he had selected Yosemite as the best location (and here he was probably conflating two different commissions, since Yosemite was not administered by the Forest Service), that he was "furnished an army mule for [his] camera equipment," that "the trip through the high mountains" took "several weeks," but that he "and his helper" had "made enough motion picture footage for a [sic] evening program and enough still pictures to fill several magazines."26

I have been unable to locate any record of a public showing of these scenic films or, indeed, any publication of the still photographs. It should be said, however, that the library of the man who acted as patron to The North American Indian, the J. Pierpont Morgan Library in New York City, does possess a series of Curtis transparencies that includes views of the Grand Canyon and other beauty spots, mule trains, and what might well be a party of VIPs. ${ }^{27}$ Of the film footage there seems to be no trace at all.

In the years after 1916 it is unlikely that Curtis made any films of his own. For one thing, Bureau of Indian Affairs policy was opposed to the kind of ethnographic films Curtis was interested in. The Annual Report of the Commissioner for Indian Affairs for 1917 carries a note to the effect that the increasing number of requests for Indians to appear in motion pictures was habitually refused unless Indians were to feature in present-day scenes, not "'made-up' exhibitions of their old time customs and dances" (U.S. Government 1918:40). In any case, as Holm and Quimby's Edward $S$. Curtis in the Land of the War Canoes shows, In the Land of the Head-Hunters had proved a financial failure, and Curtis simply did not have the money for further film ventures of its kind. In fact, in the same letter in which he first told Pliny Earl Goddard that he would be willing to part with his Kwakiutl movie, he added that he had enjoyed a very satisfactory summer of fieldwork in California and southern Oregon the previous year. "I found far more interesting material for pictures than I had expected," he said, "and my only regret is that I could not [give] more time to the trip.
Unfortunately I did not have a motion picture camera with me as funds were not available for any work along that line." In the ethnological field-if we except the 16-mm footage of Curtis's 1927 Alaska trip with his daughter Beth Curtis Magnuson, which appears in Teri McLuhan's The Shadow Catcher-there were never again funds for work "along that line."

It is, therefore, especially ironic that Curtis was simultaneously deeply involved in other people's productions for Hollywood. "I am now working," he informed Goddard on May 15, 1923, "on the picturization of the 'Ten Commandments' and aside from breaking the one which mentions the fact that we should keep the Sabbath holy, I am working about eighteen hours a day, both on said Sabbath and on the days between" (see Figure 7 ).

The Ten Commandments (1923), directed by Cecil B. De Mille, was one of the great epics of the silent cinema. As early as 1962, Ralph Andrews's Curtis' Western Indians included mention of Curtis's work as a "stills photographer" on the film (p. 56), and this is very likely, since certain ones of such images survive. ${ }^{28}$ Interestingly, De Mille himself, in his 1959 Autobiography, listed Curtis as "the second cameraman" (p. 252), and more recently film historians have also begun to record his definite employment as a movie camera operator (Higham 1973:115).

In fact, Curtis's Hollywood connections, despite the apparent absence of any screen credits at all, would repay further investigation. For instance, after his daughter Beth moved the Curtis Studio from Seattle to Los Angeles when her parents' marriage broke up just after the First World War, many of the Studio's clients for portraits were movie people, such as character actor Hobart Bosworth and screen writer John Monk Saunders. Curtis knew De Mille and D. W. Griffiths personally and was very friendly, apparently, with William S. Hart, the cowboy star, and Gene Stratton-Porter, the popular novelist, nature writer, photographer, and writer-producer for the movies. ${ }^{29}$ In the 1924 and 1926 editions of Who's Who in America Curtis listed the Screen Writers' Club among the societies to which he belonged and at least once, in 1922, he gave a friend knowing advice about writing for the cinema. ${ }^{30} \mathrm{He}$ was associated with De Mille's Adam's Rib (1923) and probably the Tarzan films, most likely the serial begun in 1921 with Elmo Lincoln in the title role. ${ }^{31}$

The last film with which Curtis seems to have had a connection was a western, The Plainsman, made in 1936 with Gary Cooper as the male lead. With an undated letter to his friend Olive Daniels, Curtis sent a photograph, now lost; the note reads, "This picture I did while working on De Milles [sic] The Plainsman. ..." 32 Along with Cooper, a fictionalized Buffalo 
Bill, and an invented General Custer, the film also featured several hundred Sioux and Cheyenne Indians who were drafted in from the Rosebud reservation. It would be interesting to know whether any of them recognized the man who, some thirty years before, in 1907, had urged numbers of their peoples to undertake a very different type of reconstruction of war and raiding parties, to follow the course of the same Little Big Horn battle, and to sit for portraits of themselves as representatives of the North American Indian for The North American Indian. ${ }^{33}$

\section{Notes}

1 I first drew attention to this item in the bibliographical notes to my anthology (Gidley 1976:190)

2 The film is available from the University of Washington Press, Seattle

3 Forrest to Andrews, October 16, 1963, Box 2, Andrews Papers, Manuscripts Division, University of Washington Libraries. Other evidence on Muhr appears in Bigart and Woodcock 1979:24-37, and Holm and Quimby 1980:23-25.

4 Gidley 1978, passim; see also the 1913 report of the fieldwork in D. C. Ewing, "The North American Indian in Forty Volumes," Art in America, 60 (July-August 1972), pp. 84-88.

5 Quoted in full in one of the publicity brochures issued by The North American Indian, Inc., The North American Indian: Extracts from Reviews of the Book, and Comments on the Work of US Author, Edward S. Curtis, n.d. Collection of the author.

8 "Seattle Man's Triumph," Seattle Times, Magazine Section, Sunday, May 22, 1904; in Biography-Curtis file, Northwest Collection, University of Washington Libraries.

7 "Sacred Rites of the Mokis and Navajoes," Seattle Times, Magazine Section, Sunday, November 27, 1904; in Biography-Curtis file, Northwest Collection, University of Washington Libraries. Interestingly, the Library of Congress Prints and Photographs Division con tains several detailed sequences of Curtis's still photographs of these ceremonies

8 The Shadow Catcher is available from Phoenix Films, New York, and from a number of rental agencies.

g Curtis to Hodge, September 26, 1906, Hodge Papers, Southwest Museum, Los Angeles. I am grateful to Ruth M. Christensen for aiding my research in these papers. Cf. the more fanciful account that follows and the one written many years later which is quoted very fully in Graybill and Boesen 1976:78-79.

10 "Seattle Man's Book in London"; quoted in full in The North American Indian (note 5, above).

11 Katherine Bartlett of the Museum of Northern Arizona, Flagstaff, kindly informed me that she thinks this is probably what happened because in Forrest's photo records, etc., there is no record of a visit to Hopi land in 1904, but there is for 1906 , though there are no known Forrest pictures of Curtis in the Museum's holdings.

12 The fullest insight into the musicale is provided, by a simulated newspaper publicity brochure, presumably issued in 1912, entitled E. S. Curtis and His Indian Picture-Opera "A Vanishing Race" Achieve Triumph. Collection of the author.

13 Both these scripts are in the collection of Karl Kernberger. I am grateful to Mr. Kernberger for granting me access to them.

14 Curtis to Hodge, March 28, 1912, Hodge Papers, Southwest Museum, Los Angeles

15 Curtis to Walcott, May 2, 1912, Smithsonian Archives, Smithsonian Institution, Washington, D.C. Quoted in full in Holm and Quimby 1980:32-33.

18 It is worth adding that the financing of the project must always have been somewhat more risky than Holm and Quimby indicate. For example, on February 17, 1913, Curtis wrote to Edgar L. Hewett, then serving as Director of Exhibits for the 1915 Panama Exposition in San Diego, suggesting that the exposition provide him with a loan to complete his film in exchange for using it as publicity. for the exposition. Interestingly, when Curtis wrote this letter he anticipated completing the film by October 1, 1913 and had been delayed thus far mainly by the months "required to get the costumes together and make those which cannot be had"; he also said he would be hiring a "first class director of motion pictures" for the film. Curtis to Hewett, February 17, 1913, Hewett Papers, Museum of New Mexico, Santa Fé

17 See Curtis to C. F. Newcombe, October 12, 1914, Newcombe Collection, Archives of British Columbia, Victoria.

18 Curtis to Clark Wissler, December 1, 1914, File 110, Anthropology Department Archives, American Museum of Natural History. New York. All subsequent American Museum letters are from this file. I am grateful to Belinda Kaye for granting me access to it. 
19 "Ethnology in Action," Independent, January 11, 1915, p. 72

20 Boas's 1930 Kwakiutl film footage, with printed notes by Bill Holm, is available from the University of Washington Press.

21 Ruby's comments appear on p. 13 of the transcript of the "Odyssey" television program devoted to Franz Boas (Boston: Public Broadcasting Associates, 1980); I am grateful to Robert Bieder for drawing my attention to this transcript.

22 In August 1980 Barbara Conklin of the Anthropology Department and Pamela Haas of the Photographic Collection assured me that the film no longer resides at the American Museum; I am grateful for their efforts on my behalf

23 Curtis to Pinchot, August 5, 1914, Gifford Pinchot Papers, Manuscript Division, Library of Congress. All subsequent Pinchot letters are from this collection. If one is to believe this letter, and there is no reason not to, Curtis did go whale killing and seal hunting in earnest; cf. doubts expressed in Holm and Quimby 1980:67-69. At the same time, the letter to Pinchot does not include details of any injuries to Curtis from a whale or of a night spent stranded on a partly submerged island, stories Curtis was to tell later (see, e.g., Graybill and Boesen, 1976:67-70).

24 Curtis to Schwinke, February 15, 1915, and May 4, 1915, Schwinke Papers, Burke Museum Archives, University of Washington, Seattle; quoted very fully in Holm and Quimby 1980:108.

25 Curtis to Meany, April 22, 1915; J. H. Weer to Meany, June 23 1915; and copy of Weer to Curtis, July 27, 1915, Meany Papers, University Archives, Records Center, University of Washington Libraries. I am grateful to Gary T. Lundell for his help in researching the Meany Papers.

28 Copy of Smith to Curtis, April 13, 1915, with letter by Curtis to Ponald Todd, July 8 [c. 1948], E. S. Curtis Vertical File, Manuscript Division, University of Washington Libraries. I would like to thank Richard Berner for aiding my research.

27 I am grateful to Thomas V. Lange of the Morgan Library for shøwing me these uncatalogued pictures.

28 The California Historical Society, San Francisco, has a number of these stills.

29 This information was kindly supplied by Curtis's family in interviews with the author: Harold P. Curtis (January 1977); Florence Curtis Graybill (December 1976 and August 1978); Manford E. Magnuson (August 1978)

30 Curtis to Meany, April 5, 1922, Meany Papers, University Archives, Records Center, University of Washington Libraries.

31 See Brownlow 1978:338-344. His brief survey relies primarily on The Shadow Catcher and interviews with Teri McLuhan. There is an Elmo Lincoln Tarzan still reproduced in a sales catalogue published by the Los Angeles photographic dealers, the G. Ray Hawkins Gallery: Edward S. Curtis Photographs (1976), illustration to item 20

32 I am grateful to the late Robert Hitchman for granting me access to this letter.

33 See the various works on De Mille cited in the references; cf. Meany: 1908.

\section{References}

- Andrews, Ralph

1962 Curtis' Western Indians. Seattle: Superior

- Bigart, Robert, and Clarence Woodcock

1979 The Rinehart Photographs: A Portfolio. Montana 29 (October):24-37.

- Brownlow, Kevin

1978 The War, the West and the Wilderness. New York: Knopf

- De Mille, Cecil B.

1959 The Autobiography of Cecil B. De Mille. Donald Hayne, ed Englewood Cliffs, N.J.: Prentice-Hall.

- Forrest, Earle R.

1961 The Snake Dance of the Hopi Indians. Los Angeles: Westernlore.

- Gidley, Mick

1978 Edward S. Curtis Speaks. .. . History of Photography 2 (October):347-354

, ed.

1976 The Vanishing Race: Selections from Edward S. Curtis's "The North American Indian." London and Newton Abbot: David \& Charles; New York: Taplinger, 1977.

- Graybill, Florence Curtis, and Victor Boesen

1976 Edward Sheriff Curtis: Visions of a Vanishing Race. New York: Thomas Crowell.

- Higham, Charles

1973 Cecil B. De Mille. New York: Scribner's

- Holm, Bill, and George Irving Quimby

1980 Edward S. Curtis in the Land of the War Canoes: A Pioneer Cinematographer in the Pacific Northwest. Seattle and London: University of Washington Press

- Lindsay, Vachel

1922 The Art of the Moving Picture. Rev. ed. New York: Liveright, 1970.

- Meany, Edmond S.

1908 Hunting Indians with a Camera. World's Work 15 (March): 10,004-10,011

- Rice, Leland

1976 Essay in exhibition catalogue, Edward S. Curtis: The Kwakiutl 1910-1914. Irvine: Fine Arts Gallery, University of California.

- U.S. Government Report

1918 Annual Report of the Commissioner for Indian Affairs. Washington, D.C. 